\title{
RESEARCH OF SATISFACTION BASED ON THE INVESTMENTS DONE IN SARKAD BETWEEN 2014 AND 2017
}

\author{
Brigitta Zsótér, Máté Szigeti \\ ${ }^{1}$ University of Szeged, Faculty of Engineering,7 Mars square, 6724, Szeged, Hungary \\ e-mail: zsoterb@mk.u-szeged.hu,szigi008@gmail.com
}

\begin{abstract}
We were searching for the first part of the development period from 2014 to 2020 in Sarkad, which mainly covers infrastructural investments. The purpose of our research is to investigate how the inhabitants think about the investments at a given time, and also to investigate the effect of the overall investments that they have experienced in Sarkad, in their own part of the city or in their own lives. The opinions of the participants in our questionnaire suggest that the upgrading's should be continued and, moreover, more investment for job facilities should be made by the local government in the city. This way, the satisfaction of the population could be maintained and the degree of emigration could be reduced.
\end{abstract}

Keywords: Sarkad, community development, hypothesis testing, infrastructural investment, Z-test, questionnaires, research of satisfaction

\section{INTRODUCTION}

On the one hand, our topic selection was based on the curiosity about the opinion of the residents of Sarkad on the local investments made since 2014 , and since we have not found any relevant research work, we have found the right topic for our joint research. Our idea was given by the Integrated Urban Development Strategy in Sarkad published in 2010, which attracted our attention in how far this project has gone off. The following questions were asked: What does the local settlement development concept contain? How does the population assess the program? How do people from Sarkad get to know with the ongoing projects?

Secondly, we chose this topic due to the fact that in 2016 several articles were published in the Local Newspaper that there are serious developments in the settlement. This was a great news for us, so we could ask the local population about some of the actual investments. It is true that the approval of most of the applications has been delayed and only took place in the second half of 2017 , so we cannot cope with the ongoing investments in this research, but it will be a promising topic later. Similar residential satisfaction measurement documents have been revised such as [1], [2] and [3]. The selection also confirmed the fact that Máte Szigeti has been living in Sarkad for 22 years, and even his father and grandfather have grown up here, so they are known in the city. This factor has helped us to get as many people as possible, because today's people's trust is very difficult to earn, but everyone has their opinion, we just need time to listen to them.

\section{MATERIALS AND METHODS}

During the ground-scouting we visited the City Manager of Sarkad, MátyásCsepreghy and the Head of the Technical and Investment Department of Sarkad, Arnold Kövári, for more information on the investments made in the past few years and planned for next year. We have explained our research goals for both of them, and asked for their opinion on what would be the important factors for them, that are included in our research as a feedback to the local government. 
We summarized our ideas and experiences gained from fieldwork. We prepared our questionnaire, which was signed on 25-26 March 2017 for a test question consisting of a ten person sample. For the sake of convenience, the participants in the trial questionnaire and the later respondents were selected from the same basic population. In addition, we did this in a similar environment [4]. The questionnaire was supplemented by protocol analysis and information summation, which provided us with relevant information about the mistakes of my questionnaire, which we could improve later on. Also, we could measure how much time it takes to fill in a questionnaire.

The responsible of the questionnaire was Máté Szigeti during the questionnaire survey, but her father helped us several times, which took place five consecutive Fridays, Saturdays and Sundays from 21 April to 21 May 2017. We have chosen the weekend days, because most of the population is not at work and there is no teaching. During our work, 365 questionnaires were filled in with the answers of the respondents.

To evaluate the data, we chose the Excel program, because we could use well-edited, varied diagrams and know the program well. [5] We applied the PSPP program to evaluate more complex relationships, such as to our hypotheses. Within this we created cross tables to get the data needed for the Z-test and a variance analysis was made to find that our hypotheses were correct or incorrect. The main thing is that it has a significant difference under the significance level of 0.05 , whereas there is no significant difference above the 0.05 significance level.

\section{RESULTS AND RATINGS}

Most of the respondents are informed by Local Sarkad City Newspaper and, on average, about 1.32 sources, indicating that it is fairly unilateral for the population of Sarkad to be informed. Nearly one-fifth of the participants in our resear ch are not satisfied with the amount of information we receive, which could be increased by getting Sarkad Tv into all households and increasing the number of resources available.

For most of the respondents (117 people), sewerage was the most important investment in the examined period. However, the restoration work was mixed, although most of them (135 people) considered this to be a bit positive, with the neutral ( 88 people) and negative responses (107 people) the whole. On average, the roads were refurbished, but the Roads of Sarkad were still poor or satisfactory.

It is true, that most people surveyed (135 people) put the equipment of surveillance cameras to the last place in the order of importance, but they still feel minimal improvement in the city's public security. Many respondents want to get feedback on whether cameras are effective and are suggesting am expansion of the number of cameras.

$70 \%$ of the respondents were unable to judge the cost price of the allowance and the amount of support. Those however, who tried to do it rightly, overestimated the cost price twice.

Most of the respondents assessed the development of the local government positively, considering the impact of the investments on their own part of town and their own lives.

Respondents to the question of population retention were almost unanimous in answering the questionnaire, so we asked for their suggestions on how to improve this factor, which is outlined in Part 5 below.

\section{HYPOTHESIS TESTING}

Our first hypothesis, in which we hypothesized that most of the respondents living in the Old Town district made the installation of the cameras in one of the first three places in the order of importance, because we believe that this is the most important investment for them in comparison to other parts of the city. No part of our first hypothesis was justified. 
For the first part of our hypothesis we used the Z-test for which the data was obtained from the questionnaire produced by the PSPP statistical program.

$$
Z=\frac{p-p_{0}}{\sqrt{\frac{p_{0} q_{0}}{n}}}=\frac{0,3489-0,50}{\sqrt{\frac{0.50 \times 0.50}{235}}}=-4.632638795207319
$$

The result of the Z-test (1) does not fall within the acceptance range between the -1.644853627 and $+\infty$ the significance level of 0.05 . According to this, less than half of the respondents living in Old Town district ranked the cameras in the first three places.

Based on the variance analysis in the PSPP program, the second part of our hypothesis revealed a significant difference between the perception of the different neighbourhoods and the exception of a district, each of the districts placed the investment we have studied compared to Old Town district.

Our second hypothesis (2), in which we thought less than one third of the respondents were dissatisfied with the quality of the post-waste recovery work, proved to be true.

$$
Z=\frac{p-p_{0}}{\sqrt{\frac{p_{0} q_{0}}{n}}}=\frac{0,29315-0,33}{\sqrt{\frac{0.33 \cdot 0.67}{365}}}=-1.497237120104014
$$

For this hypothesis, we also used the Z-test for which the data was provided from the questionnaire, 7 questionnaire by the frequency, sample mean and spreadsheet of the PSPP program. The result of the Z-test was within the acceptance range between the -1.644853627 and $+\infty$ for the significance level of 0.05 .

Our third hypothesis (3) is that the majority of respondents with at least matura examination and those with no matura examination did evaluate that their investments had a positive impact on their lives. Both parts are justified.

$$
Z=\frac{p-p_{0}}{\sqrt{\frac{p_{0} q_{0}}{n}}}=\frac{0,67907-0,50}{\sqrt{\frac{0.50 \cdot 0.50}{215}}}=5.251365847793382
$$

For the first part of our hypothesis we used the Z-test, which verified both parts of the first half of the hypothesis because the results were within the acceptance range between -1.644853627 and $+\infty$. We also conducted a variance analysis on the hypothesis that there is a correlation between the maturity of the maturity and the impact of the respondents on their post-investment life. From the post-study results, it has been found that there is a significant correlation between the two variables (significance $=0.00<0.05$ ). This suggests that graduates with matura examination and non-holders differ in the impact of investments on their lives. While those with no matura examination were 3.42 , then those with a matura examination had 3.75 of this value. Taking into account the average values of satisfaction (1-much worse, 2-bit worse, 3-same, 4-bit better, 5-better ratings) both positively evaluate the impact of investments on life, which is a justification for our hypothesis. 
In our fourth hypothesis (4), in which we thought that the opinion of the respondents in the judgment of their own neighbourhood was different, the people in the Old Town district and Northern Quarter are more satisfied, but the inhabitants of the Newly District, Industrial Park and Outdoor Areas are less satisfied. The only factor that did not justify our hypothesis was that the inhabitants in the new district appreciated their own district just as we expected.

$$
Z=\frac{p-p_{0}}{\sqrt{\frac{p_{0} q_{0}}{n}}}=\frac{0,47333-0,50}{\sqrt{\frac{0.50 \cdot 0.50}{150}}}=-0.6532789144002736
$$

Based on our hypothesis we have analysed the variance in the PSPP program, whether there is a relationship between residence and residence satisfaction. As a result, it became apparent that there was a significant difference between the satisfaction of the inhabitants in the different parts of the city (significance $=0,000<0.5$ ). Considering the average values of satisfaction (1-very negative, 2-rather negative, 3-neutral, 4-rather positive, 5-very positive rating). The average satisfaction of the Old Town residents is 3.57 , which exceeds the highest and the total average of all the city districts by five hundredth. The average rating of residents in the Northern Quarter is 3.52. This is exactly the same as the total average and the same as the inhabitants in the New District. According to this, the previous three districts are more positive by the opinion of the inhabitants. The area of the Industrial Park has an average rating of 3.15, while the average number of residents in the Outdoor Area is 2.71 . The last two results mean that industrial parks and those living in the Outside Region have had a neutral effect in their city area after the investments between 2014 and 2017.

All in all, it was found that our $1^{\text {st }}$ Hypothesis as a whole and the part of our $4^{\text {th }}$ Hypothesis based on the inhabitants in the New District did not prove to be true, while the $2^{\text {nd }}$ and the $3^{\text {rd }}$ Hypothesis as a whole, and one part of the $4^{\text {th }}$ Hypothesis proved to be true.

\section{CONCLUSIONS, SUGGESTIONS}

Our traffic development proposals compared to the respondents and for our own opinion are the following. All streets of the city should be designed to be built with an asphalt pavement road. For cross-border connections, we consider it preferable to introduce a bus service to Nagyszalonta, as there are more relatives in the two countries. There should be a dense bus service between Sarkad and Doboz, as this would relieve and make the busses going to Gyula more comfortable. By doing so, it will shorten the reach of the county seat in time and distance.

A food processing plant based on local animal and plant breeding, but the canned and textile industry was also raised in the correspondents, by which providing long-term jobs and decent wages for the residents would be easier. Even with the abolition of sugar quota, the possibility of re-launching sugar could be explored.

Establishing a complex sport meeting for all needs, serving local sports clubs, such as tennis, football, table tennis, volleyball and women's' handball. Establishment of cultural entertainment venues. The actual construction of the long promised swimming pool. Increasing the tourist utilization of the Fekete Körös. Among the proposals to extend existing institutions, we need to increase the extension of the Elderly Home, the expansion of the Nursery and the renovation of the school gymnasiums. 
Suggestions related to the environment, to solve the problems of satisfied respondents after the sewage channelling in our second hypothesis, which means deficiently restored roads and repellent nuisances. Drinking fresh water in the Gyepes Stream for most of the year. Improving lighting in the industrial park area. The preservation of the further destruction of the uninitiated houses, the calling of the owners, and ultimate transformation into a local government apartment. Settling problematic areas with public workers. Increasing attention to stray animals. Increasing the number of scapegoats and increasing the number of cameras around the various institutions, which is needed to exceed the status of cleanliness and orderliness. Also, solar cells started to be installed or even supplemented with wind power plants.

\section{ACKNOWLEDGEMENT}

This research has been supported by the Ministry of Human Capacities, Human Capacities Grant Management Office and the National Talent Program (Proj. No NTP-HHTDK-017-0004).
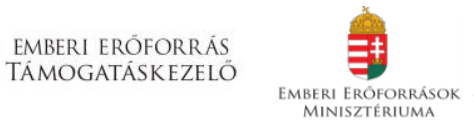

Nemzeti

Tehetség Program

\section{REFERENCES}

[1] B. T. Zsótér, L. Karácsonyi, Population's satisfaction survey related to the investments in Tápé (20042014), Társadalom földrajzi kihívások és adekvát válaszlehetőségek a XXI. század Kelet-KözépEurópájában: Nemzetközi Földrajzi Konferencia, Beregszász, 2016, kmf.uz.ua/wpcontent/uploads/kiadvanyok/Foldrajzkonf_03_14.pdf (2016.10.20.)

[2] Budakalász Város Önkormányzata, Szervezetfejlesztés Budakalász Város Önkormányzatánál, Budakalász Város Önkormányzata, Budakalász, 2014, http://www.budakalasz.hu/wpcontent/uploads/2017/01/BK_lakoss\%C3\%A1gi-el\%C3\%A9gedetts\%C3\%A9gm\%C3\%A9r\%C3\%A9s_I_k\%C3\%B6r.pdf (2016.07.10.)

[3] Újbuda Önkormányzata, Szervezetfejlesztés Budapest Főváros IX. Kerület Újbuda Önkormányzatánál, Újbuda Önkormányzata, Újbuda, 2014, http://docplayer.hu/5188160-Szervezetfejlesztes-budapestfovaros-xi-kerulet-ujbuda-onkormanyzatanal.html (2016.07.10.)

[4] N. K. Malhotra, Marketingkutatás, Akadémia Kiadó, Budapest, 2008

[5] L. Vétek, Méréskiértékelés útmutató a PSPP program használatához, PMMK Környezetmérnöki Tanszék, 2011, http://docplayer.hu/1145696-Mereskiertekeles-utmutato-a-pspp-programhasznalatahoz-pmmk-kornyezetmernoki-tanszek-2011-osszeallitotta-dr-vetek-lajos.html (2017.03.04.) 